\title{
Foreign Trade and Exchange Rate Movements in 1975
}

\author{
HANS H. HELBLING
}

NTERNATIONAL economic relations of the United States, just as domestic ones, were heavily influenced by the recession of $1974-75$ and by the resultant economic policies undertaken by most U.S. trading partners. U.S. merchandise trade responded to both the longer-term depreciation of the dollar and to differences in the severity and timing of the recessions here and abroad. Short-term fluctuations in capital movements and exchange rates were dominated by differential growth in output, differences in monetary and fiscal policies, and differences in interest rates among trading nations.

After briefly sketching economic conditions prior to 1975, this article discusses the trade and exchange rate developments which occurred during 1975. In addition, a listing of some institutional developments which will probably have an influence on international economic activity in the future is provided.

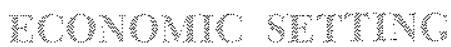

The recessions experienced in the major industrial countries in 1975 represented a continuation of a cyclical downswing which stated in late 1973. In early to mid-1973, most comtries had been concerned about high and accelerating rates of inflation and had adopted policies intended to reduce inflationary pressures. These policies usually took the form of reduced rates of monetary growth. This was most pronounced in Germany, Japan, the Netherlands, Switzerland, and the United Kingdom.

The recessions were aggravated in late 1973 when the Organization of Petroleum Exporting Countries (OPEC) imposed an embargo on oil exports. Expectations were that the embargo would adversely affect real economic growth in the industrial countries, but that business slowdowns would not degenerate into severe recessions, In addition, stmulative economic policies were considered inappropriate at this time, as policymakers were still concened with inflation.

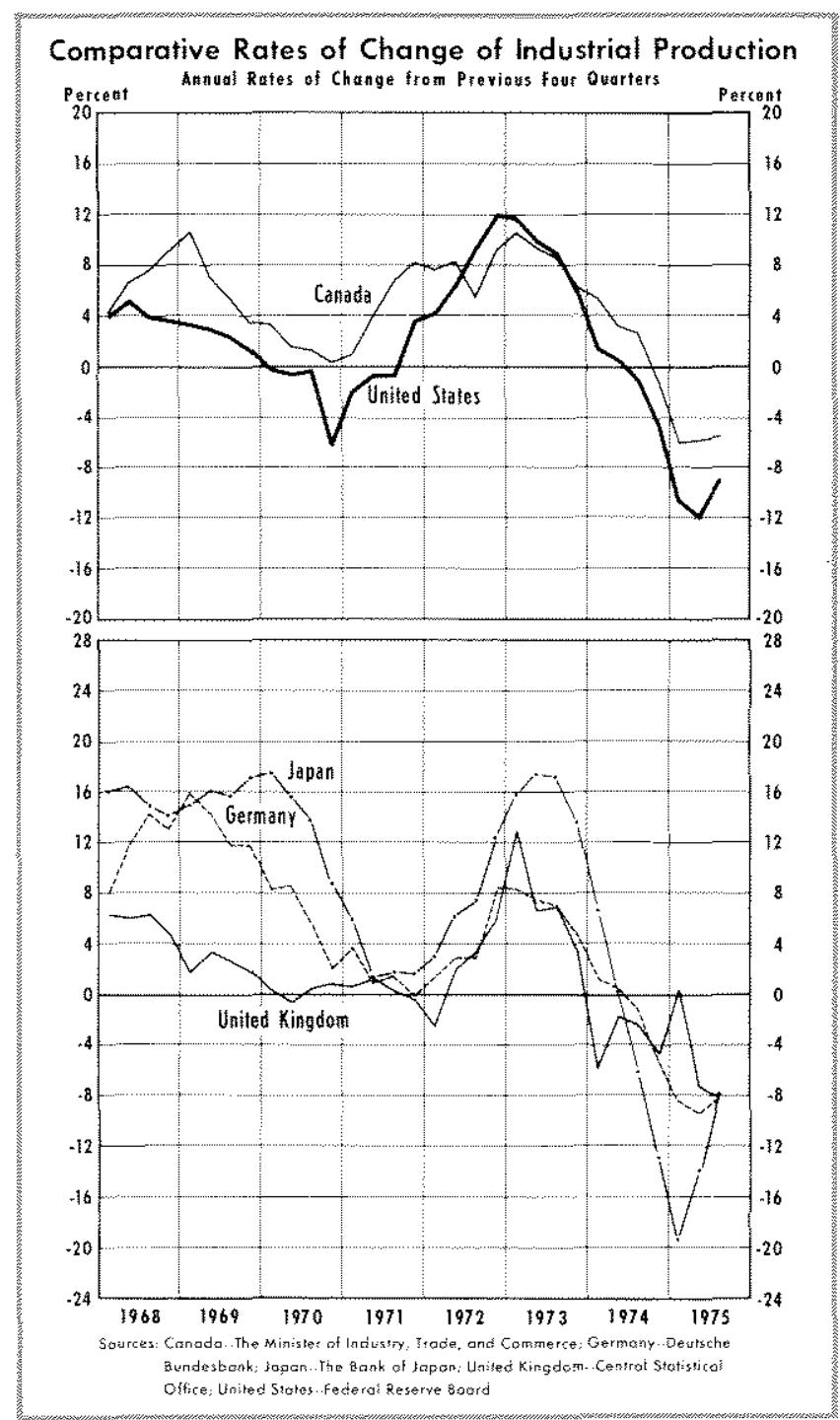

Toward the end of 1974 and into early 1975, however, economic conditions in most combries deteriorated more rapidly than expected, and most foreign countries responded with stimulative monetary policies. In contrast, monetary growth declined in the United States from the third quarter of 1974 through the first quarter of 1975 . 


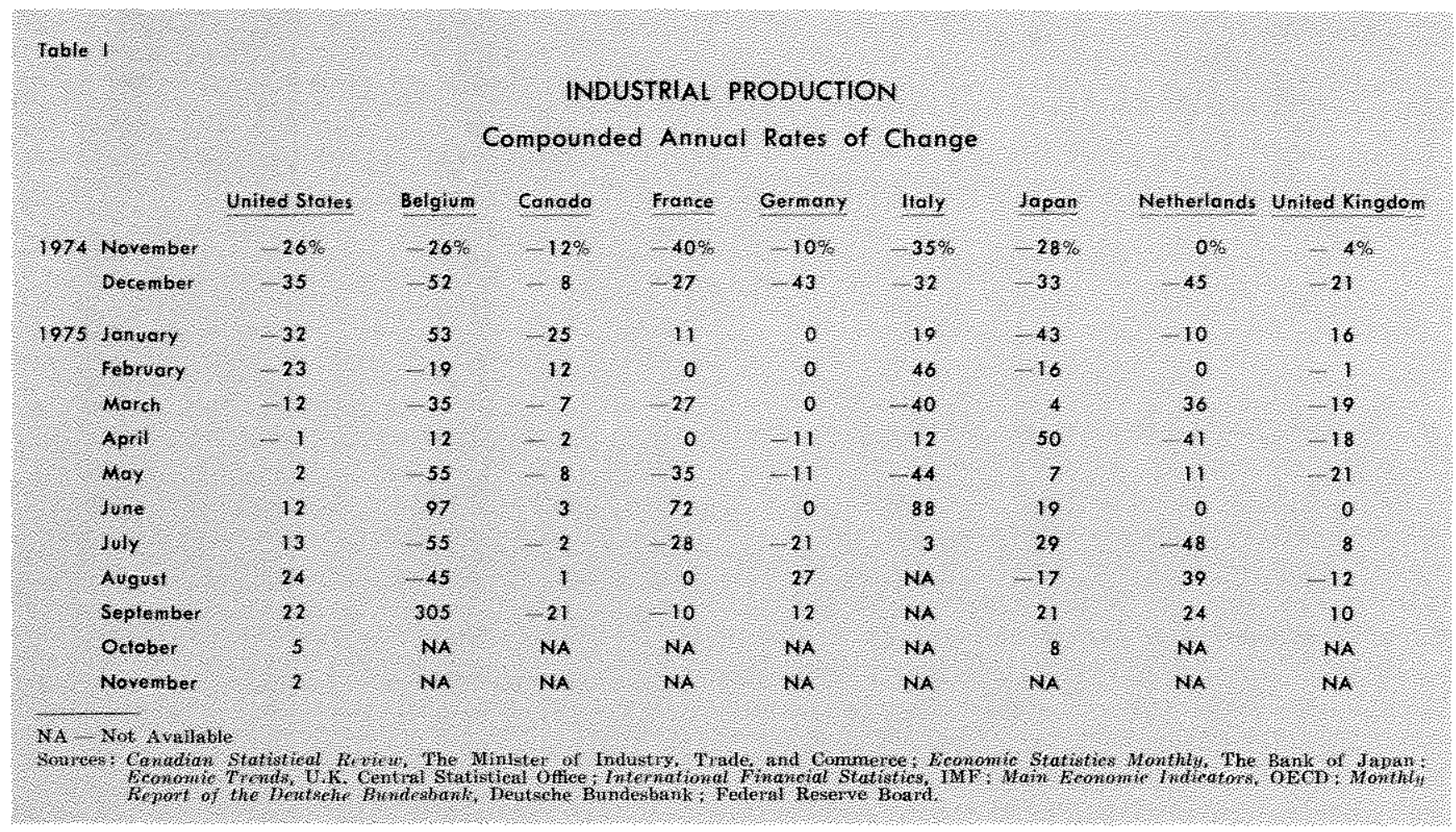

In early 1975 the consensus among analysts was that real economic growth in most industrial countries would resume in the second half of 1975 , with recovery abroad preceding that of the United States. By mid-year, however, the U.S. economy appeared to be moving out of the recession, while its major trading partners were still searching the economic horizon for signs of a turnaround. ${ }^{1}$

As economic activity in the United States improved early in the second half of 1975, many foreign policymakers became impatient with the pace of recovery (or lack thereof) in their own countries. Suspecting that more stimulus on the part of the United States would not be forthcoming, many foreign governments adopted a new series of economic policy measures, mainly in the fiscal area. For example, in August Germany announced a supplenentary budget proposing an increase in expenditures of more than 15 billion marks for new construction programs and unemployment assistance. Denmark, at that time, also announced a new program to stimulate the economy via a combination of tax reductions and expenditure increases. Beginning in September, various other gov-

${ }^{1}$ For example, an economic forecast issued in October by $\mathrm{OECD}$ for the organization's 24 member countries suggested a corm bined annual rate of decline of 2.5 percent. In fuly, for comparison, the organization's forecast suggested a dedine of GNP of only 1.5 percent. However, in its October forecast, the OECD noted, that for the member countries as a whole, the low point in economic activity has already passed. ernments, including Belgium, France, Japan, the Netherlands, and the United Kingdom, also announced the introduction of stimulative fiscal measures. At this time it appears that the economies of Canada, Germany, and Japan, in addition to the United States, have moved out of the recession, while for many other countries a turnaround has not yet materialized.

In summary, the economies of major industrial countries were in different stages of recovery during 1975. Adjustments to prior output shocks and restraints were nearing completion and stimulative fiscal and monetary policies were beginning to take effect. While the recovery was relatively strong in the United States, it was just beginning to manifest itself in some of the foreign trading nations in the latter half of the year. Thus, the differential rates of economic recovery were primarily responsible in shaping international transactions in 1975.

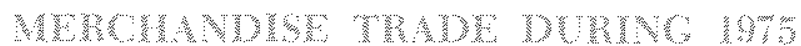

The depth of the U.S. recession, as well as the decline in the international value of the dollar which began in 1971, manifested itself in smaller U.S. purchases from, and relatively larger U.S. sales to, foreign trading partners. This resulted in a $\$ 10.6$ billion excess of U.S. merchandise exports over imports in the first eleven months of 1975 . Beside the depreciation of the 


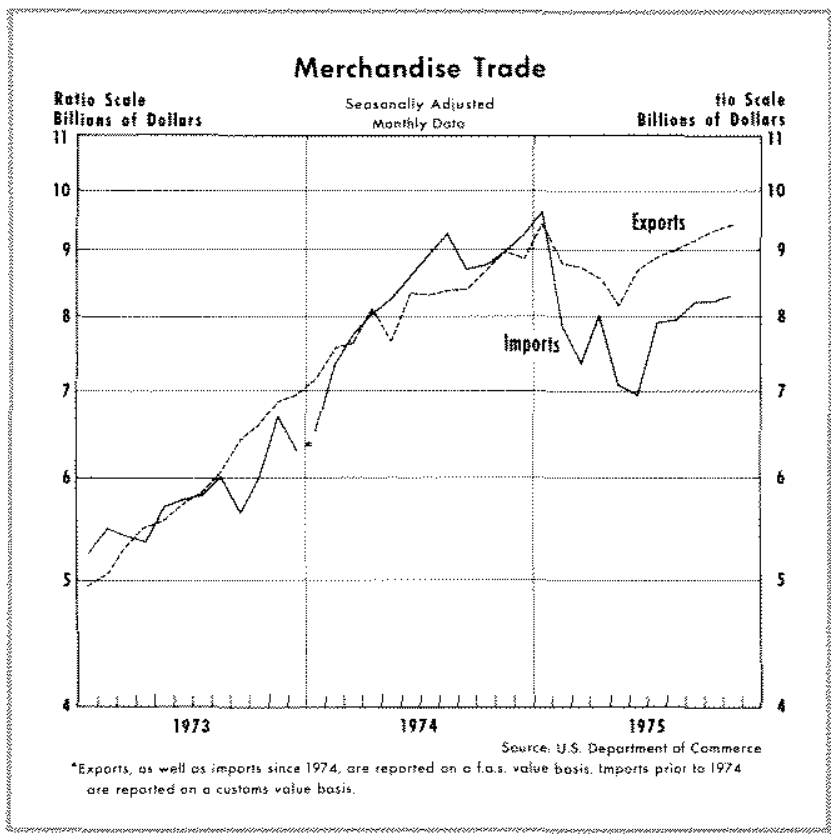

dollar, some additional factors contributed to this turnaround in U.S. merchandise trade. Agricultural exports remained relatively high and OPEC purchases of U.S. goods increased from about $\$ 4$ billion in the first three quarters of 1974 to about $\$ 7$ billion in the first three cuarters of 1975.

While in the first quarter of 1975 the rate of increase of U.S. merchandise exports slowed to a 9 percent annual rate (compared to a 28 percent anmual rate in the fourth quarter of 1974), U.S. imports decreased absolutely at a 33 percent amnual rate (compared to a 10 percent annual rate of increase in the fourth quarter)..$^{2}$

During the second quarter of 1975 , U.S. merchandise exports exceeded merchandise imports by an impressive $\$ 13.4$ billion amual rate. In this period both exports and imports deelined absolutely at annual rates of 20 percent and 40 percent. respectively.

During the third quarter. U.S. merchandise exports still exceeded imports, but by less than during the second quarter. This oecurred as both merchandise exports and imports shifted from negative to positive rates of growth. In terms of product categories, U.S. agricultural exports increased somewhat compared to last year, and manufactured goods, such as machinery and transport equipment, increased substantially over 1974. While merchandise exports to Japan declined during the first half of 1975 . those to Westem Europe increased.

The growth rates at merchandise trade are calculated from balance-of-payments data.

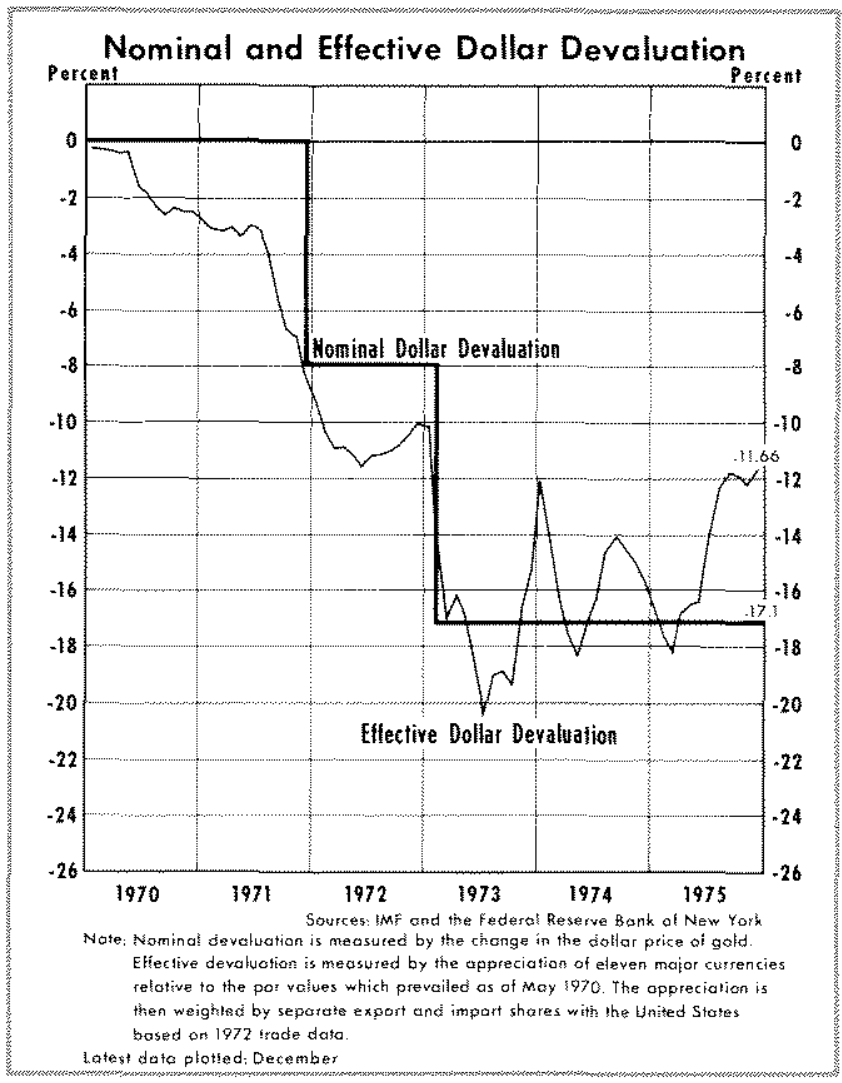

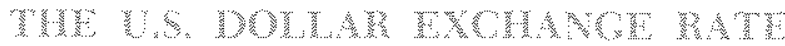

On balance, the U.S. dollar appreciated during 1975. However, there were two distinct exchange rate phases in 1975 during which the U.S. dollar first fell and then rose in value vis a vis the major foreign currencies. The first phase extended through the first quarter of 1975; the second phase extended from April to the present.

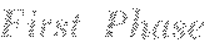

The dollar exchange rate began to depreciate in September 1974 and continued to decline through the middle of the first quarter of 1975. As measured on a trade-weighted basis, the international value of the dollar in September 1974 was 14 percent below its May 1970 value. ${ }^{3}$ In March 1975 the dollar's value had fallen 18 percent below its May 1970 value a 29 percent decline from September 1974 .

The general decline in the value of the dollar dur ing this period may be attributed to interest sensitive short-term capital outflows. Because the dechine in business activity was generally more pronounced in the United States than abroad, a sharp drop in the

3The trade-weighted dollar depreciation is measured by the appreciation of eleven major currencies relative to the par values which prevailed as of May 1970. 


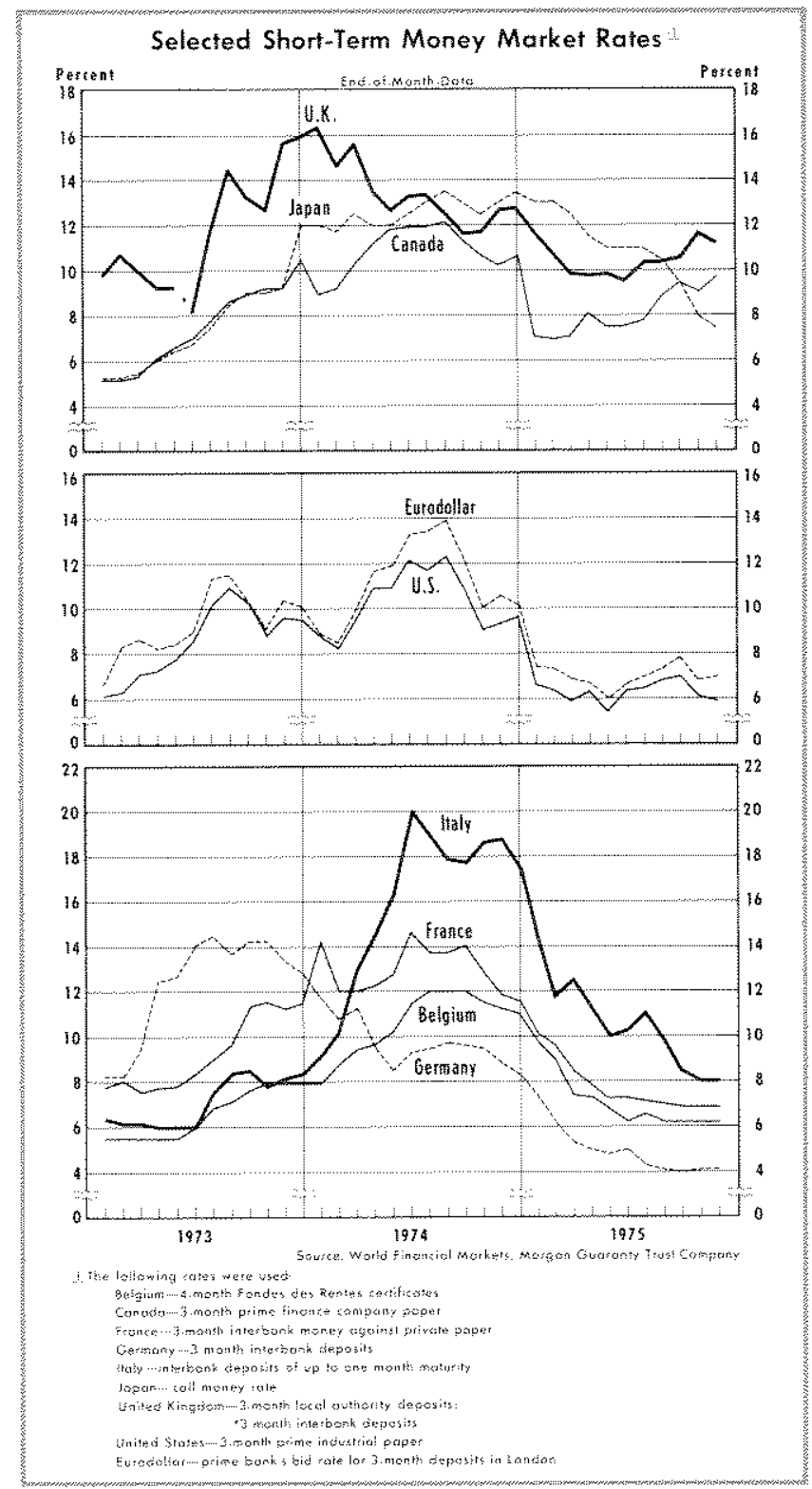

demand for credit resulted in a decline in U.S. shortterm interest rates relative to those in other countries. As illustrated in the accompanying chart and in Table II. during the first quarter of 1975 , U.S. short-term interest rates were falling relative to those in Belgium, France, Germany, and the United Kingdom. As a result, the incentive to invest in these countries increased and holders of short-term dollar-denominated assets switched to short-term assets denominated in other currencies.

\section{Second phas:}

Several developments began during the second quarter of 1975 which led to the appreciation of the doltar. Various economic indicators in the United
States conveyed signs of impending economic recovery, while, as was mentioned earlier, recovery abroad was not yet visible. In addition, U.S. short-term interest rates began to rise relative to short-term rates in other countries. As a result, the incentives for short-tem capital inflows began to shift in favor of the United States. During the second quarter, net shortterm private capital outfows decreased from the first quarter annual rate of $\$ 25.5$ billion to an annual rate of $\$ 10.6$ billion.

During the third quarter a continuation of the second quarter trend led to a further appreciation of the dollar. Short-term interest rate differentials increasingly favored inflows of shortuterm private capital into the United States, and the United States registered a third quarter net inflow of short-term private capital of $\$ 18.5$ billion. Thus, the appreciation of the U.S. dollar during the second and third quarter can be largely attributed to both the rise in U.S. short-term interest rates relative to those in other countries and the subsequent changes in short-tem capital flows.

\section{MUM M 197}

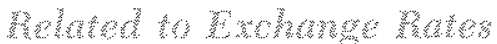

The first quarter decline of the dollar exchange rate precipitated changes in some institutional arrangements within the area of international finance. For eximple, in mid-March four Middle East countries severed the link between their currencies and the U.S, dollar. Iran, Saudi Arabia, Kuwait, and Quatar announced the decision to tie the exchange rates of their currencies to SDRs.

In addition, the European Economic Community in late March decided to terminate the relationship between the communities' Unit of Account (UA) and the U.S. dollar.* The UA is now valued in terms of a basket of member country currencies. The intent was to insulate internal EEC financial settlements from Huctuations in exchange ates of member countries vis à vis the U.S. dollar.

In June, OPEC decided to replace the U.S. dollar with SDRs for valuation of oil as of October 1 . However, on October I OPEC reversed its previous decision and decided to retain the U.S. dollar as the currency in which oil prices are denominated. In June

4The Unit of Accoun (UA) is the basis for each member comntries financial relationship with the commanity. For example, payments and contributions under the common agricultural policy and the commonity bughet ane expressed in terms of Units of Account. 


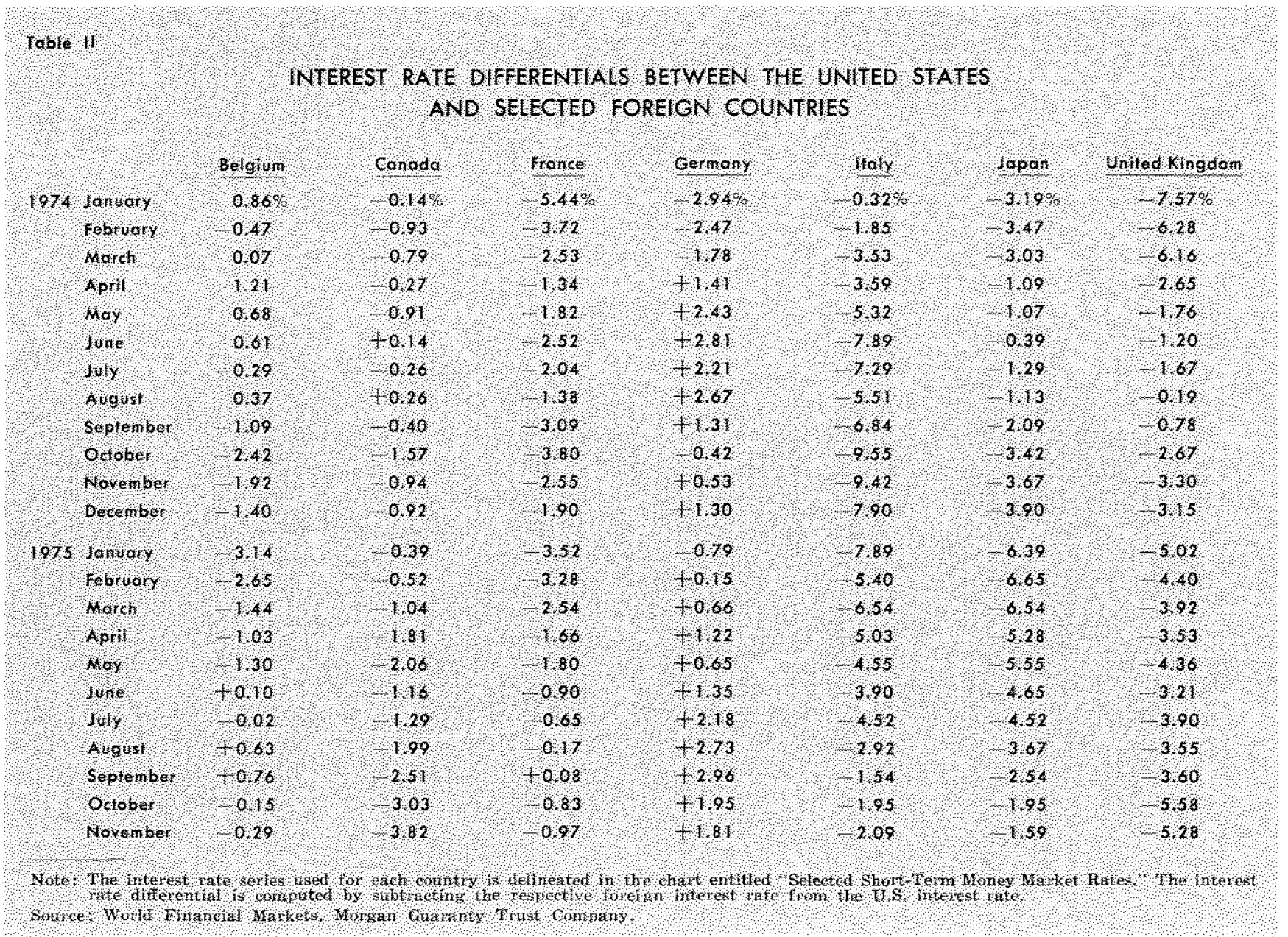

the SDR was equivalent to about $\$ 1.25$ and the dollar had been declining. Currently, the SDR is equivalent to about $\$ 1.17$ and the dollar has been rising. As a result of this rise in the value of the dollar relative to the SDR, it became advantageous for OPEC to continue the dollar-oil price valuation.

Another event which was related to exchange rates was the decision by France in July to rejoin the European currency foat known as the "Snake." This arrangement was instituted in March 1973 in order to maintain a maximum margin of \pm 2.25 percent for exchange rate fluctuations in transactions among member currencies. France had withdrawn from the "Snake" in January 1974. Presently, the comtries participating in the "Snake" are Belgium, Denmark, Germany, Luxembourg, the Netherlands, Norway, Sweden, and France.

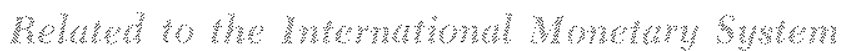

In early September, the Intemational Monetary Fund (IMF) held its annual meeting and reached agreement on steps to reduce further the role of gold in the intemational monetary system. In essence, the 127 member countries of the IMF agreed to terminate the concept of the "official price" of gold. It was agreed that one-sixth of the gold stock currently held by the IMF ( 25.6 million ounces) would be gradually sold over the next two years. Another one-sixth will be returned to nember countries in proportion to their original contributions. No agreement was renched, however, regarding the nature of a future exchange rate system.

In mid-November an economic summit meeting of the heads of state and finance ministers of the United States, France, Germany, Great Britain, Italy, and Japan was held in Rambouillet, France. The purpose of the meeting was to coordinate economic policies of the participating countries. The communique issued at the end of the meeting consisted primarily of general statements about the common pursuit of policies that would reduce unemployment and inflation. Of significance, however, was the agree ment to counter erratic fluctuations in exchange rates. 
Although the communique did not specify how erratic exchange rate fluctuations are to be removed, outside observers generally believed that official intervention in foreign exchange markets was the tool with which to achieve these goals. Moreover, the communique noted that a rapprochement of U.S. and French views regarding the international monetary system was achieved and that this would facilitate agreement on outstanding issues of intemational monetary reform.

Finally, in early January 1976 a meeting of the Interim Committee of the IMF was convened in Jamaica for the purpose of discussing these outstanding issues. At this meeting an agreement was reached among the 127 member countries of the IMF permitting individual member countries the option to choose from among three types of exchange rate systems. Individual countries will have the option of either adopting a floating exchange rate system, pegging their currencies to other currencies, or establishing a par value for their currency in terms of SDRs. In addition, it was agreed that a general par value system could be reintroduced if 85 pereent of the member countries' votes favored such a step. Presently, the votes of the United States represent about 20 percent of the total.

Of particular significance was the agreement that the floating exchange rate system would take the form of a "clean" float. That is, countries who avail themselves of floating exchange rates should "avoid manipulating exchange rates ... . in order to prevent effective balance-of-payments adjustment or to gain an unfair competitive advantage over other members."

To achieve a "clean" float, countries are required to "seek to promote stability by fostering orderly underlying economic and financial conditions and a monetary system that does not tend to produce erratic disruptions." "The above requirement is consistent with the view that stable underlying economic conditions are conducive to stable exchange market conditions.

\section{BUNANA}

During 1975 the world economy was subjected to the forces of recession. The U.S. recession was both more severe and more short-lived than that of its trading partners. This, in tum, was conducive to first a declining and then to a rising U.S. dollar exchange rate, U.S. trade performance was affected by these developments, as witnessed by the fact that U.S. merchandise exports exceeded U.S. merchandise imports by $\$ 10.6$ billion during the first eleven months of 1975 .

Aithough early in 1975 there were expectations that foreign economic recovery would precede that of the United States, it turned out that foreign economic recovery was, and in some cases still is, lagging behind that of the United States. It is expected, however, that economic growth in most industrial countries will resume in 1976 , though at relatively low rates.

The Wall Street Joumal, Jamuary 12, 1976.

"Ibid,

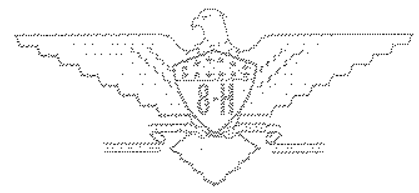

